\title{
Interactions between nutrition and the intestinal microflora
}

\author{
BY CHRISTINE EDWARDS \\ Department of Human Nutrition, Glasgow University, Yorkhill Hospitals, Glasgow G3 8SJ
}

The human gut is well colonized by a wide variety of bacteria. In the industrial nations, the stomach and small intestine have a sparse flora protected by gastric acid and a highly propulsive motility. The flora of the small intestine increases along its length and particularly in the terminal ileum (Drasar \& Hill, 1974). The large intestine has a very rich, mainly anaerobic, flora capable of fermenting carbohydrate and protein, and metabolizing a wide and diverse range of endogenous and exogenous molecules such as bile acids, fats and drugs. In the less-developed countries the small intestine has heavier populations of bacteria and these may be a factor in the higher occurrence of diarrhoea and malnutrition (Gorbach et al. 1970; Gracey, 1979).

The interactions between nutrition and the intestinal microflora are complex. Bacteria in the gut may affect digestion and absorption, the products of bacterial fermentation may provide nutrients or affect the well-being of the host, but diet may also affect the survival and metabolism of the bacteria. The products of bacterial metabolism may be beneficial, for example butyrate which may have anti-neoplastic properties (Augeron \& Laboisse, 1984), or they may be potentially harmful, for example bile acid metabolites which may be co-carcinogenic (Owen et al. 1987). The interaction between the intestinal microflora and nutrition begins at birth and changes with age and disease.

\section{NEONATAL MICROFLORA AND NUTRITION}

At birth a baby encounters bacteria for the first time and quickly develops a commensal microflora on its skin and along its gastrointestinal tract. The factors which determine the initial colonization are not fully understood but must relate to environment, including the birth canal, and to diet. The faecal microflora of babies fed exclusively on mother's breast milk differs in many ways from that of babies fed on formula milk derived from cow's milk. The faecal flora of a breast-fed baby is more likely to have bifidobacteria and lactobacilli as the predominant organisms with lower amounts of Enterobacteriaceae and few bacteroides species (Bullen et al. 1977; Balmer \& Wharton, 1989a). The bottle-fed baby has a faecal flora which resembles the adult more closely, with more Enterobacteriaceae and streptococci and more bacteroides species. This difference is not always seen, however. Simhon et al. (1982) could find no difference in the microflora of breast-fed and bottle-fed babies in a study in London and suggested that this may be due to a difference in the obstetric practice resulting in different environmental factors which influence initial colonization. The difference between microflora of breast-fed and formula-fed babies is reflected in the profile of bacterial fermentation products in faeces, with a lower faecal pH (Bullen et al. 1977) and a more predominant acetic/lactic acid-type fermentation in breast-fed compared with formula-fed babies (Bullen et al. 1977; C. A. Edwards, S. F. Balmer, A. P. Parrett \& B. A. Wharton, unpublished results).

The dietary factors which may influence the different colonization of the gut of 
breast-fed and formula-fed infants are numerous. They include the buffering capacity, the casein/whey and phosphate content, and the concentrations of oligosaccharides, bifidus factor, human proteins such as secretory IgA and lactoferrin, and other micronutrients such as $\mathrm{Fe}$ and nucleotides. The exact role of each of these factors is difficult to study in isolation in vivo but modern formulas now mimic human milk in many ways with very little real change in the faecal flora. Balmer \& Wharton $(1989 a, b)$ and Balmer et al. (1989) have carried out several studies looking at the effect of dietary factors in formula milk on the faecal flora and found that whey-protein-predominant formula produced a higher prevalence of bifidobacteria and less bacteroides species than casein-predominant formula. The role of the $\mathrm{Fe}$ content of milk and the role of lactoferrin was less clear. Human milk contains less Fe than formula milks but it is more efficiently absorbed. Fe which remains in the gut is available for the growth of potential pathogens. Much of the free Fe in the gut of the breast-fed baby is probably bound to lactoferrin and is unavailable for bacteria. Bifidobacteria and lactobacilli do not need significant amounts of $\mathrm{Fe}$ for growth (Archibald, 1983). However, although whey formula without $\mathrm{Fe}$ reduced levels of enterococci and clostridia (Balmer \& Wharton, 1991), the faeces of babies fed on low-Fe formula was more dissimilar to those of breast-fed babies than those of babies fed on a whey formula with Fe (Mevissen-Verhage et al. 1985; Balmer \& Wharton, 1991). The nucleotides in human milk may affect the gut microflora either indirectly by increasing Fe absorption in the small intestine (Faelli \& Esposito, 1970; McMillan et al. 1977) or by stimulating the growth of bifidobacteria. Addition of a selection of nucleotides to in vitro cultures increased the growth of bifidobacteria and when added to infant formula have produced a faecal flora more similar to that of a group of breast-fed babies (Gil et al. 1986). Other dietary factors such as the concentrations of IgA or oligosaccharides have not yet been investigated in much detail. The differences in faecal flora must relate to a whole range of dietary differences between human and formula milk and not to a single element. However, they do indicate the importance of diet in the establishment of the gut microflora and are related to a difference in the gastrointestinal infection rate in babies. Howie et al. (1990), showed that breast-fed babies had a lower incidence of gastrointestinal infections than formulafed babies even after compounding factors such as social class had been accounted for.

In addition, the colonic microflora may also be important in salvaging unabsorbed carbohydrate and in cycling $\mathrm{N}$ in the neonate. Premature babies may have insufficient lactase $(E C 3.2 .1 .108)$ in the small intestine and, thus, significant amounts of unabsorbed sugar enter the colon. This sugar is fermented by the colonic microflora to short-chain fatty acids (SCFA) and $\mathrm{H}_{2}$, which are absorbed, preventing osmotic diarrhoea and conserving energy (MacLean \& Fink, 1980; Mobassaleh et al. 1985; Kien et al. 1987). Protein digestion by the colonic bacteria and absorption of $\mathrm{N}$ may also occur in the colon of neonates (Heine et al. 1987). This dependence on the colonic microflora for nutrient absorption indicates a need to consider the effects of antibiotics on nutrition in small babies (Bhatia et al. 1986).

Little is known of the factors which affect the changes in the microflora during weaning. The flora develops towards the adult flora, the bacteria becoming more numerous and the ecosystem more complex with a greater predominance of Escherichia coli, streptococci, clostridia and bacteroides species (Bullen et al. 1976). Studies in rats have suggested that the exposure of the microflora to a particular substrate at weaning may determine the response to that substrate in adult life (Armstrong et al. 1992). This 
study in rats looked at complex carbohydrates but the same could be true for other dietary components and endogenous secretions.

\section{ADULT MICROFLORA AND NUTRITION}

The normal adult microflora and its fermentation pathways and patterns have been described elsewhere in this symposium. In the present paper I have concentrated on the consequences of the bacterial activity and how this relates to nutrition.

\section{Effect of diet on bacteria}

Bacteria in the human colon vary substantially from person to person both in the species present and in their fermentation capacity and product profile. The capacity of a person's microflora to ferment different carbohydrates depends on past diet and the species of bacteria present. The faecal flora of adults is remarkably stable, with many studies looking at the effect of dietary change on the bacterial populations showing no real effect (Bornside, 1978; Hill, 1981). As some dietary fibres increase stool output and colonic content turnover, they increase bacterial turnover and populations. Indeed, for some fibres this increased bulk of bacterial cells is the major component of the increase in stool weight (Stephen \& Cummings, 1980). The colonic fermentation capacity, rate of fermentation and range of SCFA and gaseous products are also altered by feeding fermentable carbohydrates. In vitro cultures of human faeces supplemented with starch, wheat bran and oat fibre produced substantial amounts of butyrate whereas arabinoglucan, ispaghula, guar gum and starch produced large proportions of propionate (Englyst et al. 1987; McBurney \& Thompson, 1987; Adiotomre et al. 1990; Edwards et al. 1992a,b; Weaver et al. 1992). These patterns were also demonstrated in the faeces of rats and other animals fed on similar fibres (Mallett et al. 1988; Topping et al. 1988; Goodlad \& Mathers, 1990; Edwards \& Eastwood, 1992).

The polysaccharidase enzymes required for the breakdown of some carbohydrates are subject to dietary regulation; their activity is induced by exposure to the substrate and expression may be repressed by products of the fermentation reaction (Salyers \& Leedle, 1983). Florent et al. (1985) intubated the caecum of human volunteers and fed them on lactulose for 1 week. They found that the $\mathrm{pH}$ of the colon was reduced and the pattern of fermentation was changed at the end of the week, with a more rapid degradation of lactulose, a faster accumulation and clearance of intermediates and decreased $\mathrm{H}_{2}$ production. Other researchers report increased capacity to ferment fibres after ingestion for 1 week (Read \& Eastwood, 1992) and studies in rats indicate at least 4 weeks of feeding is necessary before full fermentation capacity is achieved (Walter et al. 1986).

\section{Nutritional consequences of colonic fermentation}

The major consequences of carbohydrate fermentation in the colon are the loss of water-holding capacity (WHC) of certain fermentable dietary fibres, production of SCFA and gases, decreased $\mathrm{pH}$, release of bound molecules from dietary fibre, production of bacterial cells and, hence, changes in the expression of other bacterial enzymes that have important physiological implications.

The most obvious effect of colonic bacteria on a food is the fermentation of dietary 
fibre and resistant starch. The impact of bacterial fermentation on the physiological effects of these can be seen when fermentable substrates are eaten by people taking antibiotics. Kurpad \& Shetty (1986) showed that fibre had a much greater effect on stool output when subjects were also taking antimicrobial agents. The capacity of individuals to ingest lactulose without an increase in stool output was also decreased by ampicillin (Rao et al. 1988). The WHC of a dietary fibre is an important factor in its effect on stool output. However, many dietary fibres with high WHC have very little effect on stool output. This is because of bacterial degradation of the fibre in the colon. The post-fermentation WHC (measured in vitro) is the best indicator of action on stool output (McBurney et al. 1985).

An increase in stool output has several nutritional implications. Increased faecal mass includes an increased loss of $\mathrm{N}$, energy, water and electrolytes. There may be an increased loss of bile acid metabolites and other potential toxins which may decrease the risk of mucosal damage and alter the bile acid pool.

The SCFA produced during carbohydrate fermentation also have several possible nutritional actions. They are rapidly absorbed by the colonic mucosa promoting water and $\mathrm{Na}$ absorption (Ruppin et al. 1980) and preventing osmotic diarrhoea in situations of small intestinal malabsorption of sugars. The colonic mucosa may use the SCFA as a preferential energy source, especially butyrate (Roediger, 1982). Very little butyrate is seen in the blood draining from the large intestine and propionate is metabolized in the liver, leaving acetate as the only SCFA to be seen in the systemic blood under normal conditions (Cummings et al. 1987). The SCFA may also have several other effects in the colonic lumen. SCFA in the colonic lumen may increase cellular proliferation of the colonic epithelia (Sakata, 1987) and may increase proliferation of the mucosa of the small intestine by a blood-borne factor (Sakata, 1989). Butyrate has been shown to stimulate differentiation of cancer cell lines (Augeron \& Laboisse, 1984). SCFA in the lumen may also have effects on colonic motility but their exact role on propulsive or segmenting contractile activity is unclear. In isolated rat colon muscle strips propionic and butyric acid stimulated contraction (Yajima, 1985), whereas in an isolated rat caecal/colon model a mixture of SCFA decreased overall colonic motor activity (Squires et al. 1992). SCFA have also been shown to dilate arterial capillaries and may, thus, affect blood flow and absorption rate from the colon (Mortensen et al. 1990).

Propionic acid is reported to have an influence, in the liver, on gluconeogenesis and cholesterol synthesis (Anderson \& Bridges, 1984; Chen et al. 1984) but the concentrations necessary for these actions may not be achieved in vivo under normal conditions (Illman et al. 1988). The metabolism of SCFA by the tissues may represent a significant component of the daily energy intake up to $7 \%$ (Cummings, 1981) and the energy value of fermentable dietary fibre may be from 0 to $17 \mathrm{~kJ} / \mathrm{g}$ ( 0 to $4 \mathrm{kcal} / \mathrm{g})$ depending on the calculation method (Wisker \& Feldheim, 1992). The energy gained by utilization of SCFA may, in some part, be offset by the increased faecal losses that often occur with the intake of these dietary fibre sources (Wisker \& Feldheim, 1990).

The fermentation of dietary fibre sources by bacteria may also release sequestered molecules such as $\mathrm{Ca}$ and bile acids and these may then be available for absorption, in some cases after further bacterial metabolism. Bacteria deconjugate and dehydroxylate bile acids altering the composition and properties of the bile acid pool and also producing possible colonic cancer promoters. Bile acid metabolites and bacterially hydroxylated fatty acids may cause secretion (Mekhijian et al. 1971) and stimulate colonic motility 
(Kirwan et al. 1975; Spiller et al. 1986). SCFA are potent inhibitors of pathogenic bacteria (Fay \& Faires, 1975) along with deconjugated bile acids (Floch et al. 1972) and so the commensal bacteria help to prevent gastrointestinal infection.

It is generally believed that on a mixed diet most fermentation takes place in the proximal colon of man but experiments in rats suggest that some non-starch polysaccharides, such as xanthan and karaya, which are slowly fermented may spread the production of SCFA into the more distal colon where they may have less effect on colonic cellular proliferation (Edwards et al. 1992a,b) but may promote an increase in faecal water excretion (Edwards et al. 1990). Some fibres such as wheat bran, which were shown to produce significant amounts of butyrate in vitro, may be fermented mainly in the proximal colon so that butyrate in the distal colon, where cancer and colitic disease is more common, is unaffected (Edwards \& Eastwood, 1992). Other fibres such as ispaghula, which are more often associated with propionic acid production, may in fact increase distal colonic butyrate to a greater extent (Edwards \& Eastwood, 1992). It has recently been shown that rectal infusions of SCFA into the colons of patients with active colitis improved symptoms and disease activity (Breuer et al. 1991).

Rapid fermentation in the colon, as with lactulose or some highly fermentable fibres, may produce a substantial decrease in colonic $\mathrm{pH}$ which may have several effects. Bile acids may be precipitated, reducing their absorption and actions on the colonic mucosa and the $7-\alpha$-dehydroxylase enzyme will also be inhibited. Bacterial production and absorption of $\mathrm{NH}_{3}$ may be inhibited (Swales et al. 1970; Vince et al. 1978) and colonic cellular proliferation may be stimulated (Lupton et al. 1988).

Increased bacterial populations may result in increased activity of certain enzymes such as $\beta$-glucuronidase, $\beta$-glucosidase $(E C$ 3.2.1.21) and azoreductase (EC 1.6.6.7) which are involved in the metabolism of exogenous molecules such as drugs and possible carcinogens (Rowland \& Mallett, 1990). $\beta$-Glucuronidase and $\beta$-glucosidase may reactivate toxins previously deactivated in the liver (Mallett \& Rowland, 1990). Fermentable carbohydrate sources often increase the activity of these enzymes (Rowland \& Mallett, 1990) but the effects are not always consistent and no definite role for the enzymes in carcinogenesis has been proved. However, in rats fed on carcinogens as well as fermentable fibre tumour yield was increased in the colon (Jacobs, 1990). This may be due in part to the stimulation of cellular proliferation by SCFA as well as an increase in the active carcinogen.

\section{CONCLUSION}

The intestinal microflora and the nutrition of the host have several complicated but important interactions which start at birth and develop as the populations and number of species increase, the ecosystem becomes more stable and new bacterial substrates are ingested. Some of these interactions are beneficial to the host but some may be detrimental. However, the activity of the bacteria in the human colon is complex and very little understood at present.

\section{REFERENCES}

Adiotomre, J., Eastwood, M. A., Edwards, C. A. \& Brydon, W. G. (1990). Dietary fibre; in vitro methods that anticipate nutrition and metabolic activity in humans. American Journal of Clinical Nutrition 52, $128-134$. 
Anderson, J. W. \& Bridges, S. R. (1984). Short chain fatty acid fermentation products of plant fibre affect glucose metabolism of isolated rat hepatocytes. Proceedings of the Society of Experimental Biology and Medicine 177, 372-376.

Archibald, F. S. (1983), Lactobacillus plantarum an organism not requiring iron. FEMS Microbiology Letters 19, 29-32.

Armstrong, L. F., Eastwood, M. A., Edwards, C. A., Brydon, W. G. \& Macintyre, C. C. A. (1992). The effect of weaning diet on the subsequent colonic metabolism of dietary fibre in the adult rat. British Journal of Nutrition 68, 741-751.

Augeron, C. \& Laboisse, C. L. (1984). Emergence of permanently differentiated cell clones in a human colonic cancer cell line in culture after treatment with sodium butyrate. Cancer Research 44, 3961-3969.

Balmer, S. E., Scott, P. H. \& Wharton, B. A. (1989). Diet and faecal flora in the newborn: casein and whey proteins. Archives of Disease in Childhood 64, 1678-1684.

Balmer, S. E. \& Wharton, B. A. (1989a). Diet and faecal flora in the newborn: breast milk and infant formula. Archives of Disease in Childhood 64, 1672-1677.

Balmer, S. E. \& Wharton, B. A. (1989b). Diet and faecal flora in the newborn: lactoferrin. Archives of Disease in Childhood 64, 1685-1690.

Balmer, S. E. \& Wharton, B. A. (1991). Diet and faecal flora in the newborn: iron. Archives of Disease in Childhood 66, 1390-1394.

Bhatia, J., Prihoda, A. R. \& Richardson, C. J. (1986). Parenteral antibiotics and carbohydrate intolerance in term neonates. American Journal of Disease in Childhood 140, 111-113.

Bornside, G. H. (1978). Stability of human fecal flora. American Journal of Clinical Nutrition 31, S141-S144.

Breuer, R. I., Butro, S. K., Christ, M. L., Bean, J., Vernia, P., Paoluzi, P., Di Paolo, M. C. \& Caprilli, R. (1991). Rectal irrigation with short chain fatty acids for distal ulcerative colitis. Digestive Diseases and Sciences 36, 185-187.

Bullen, C. L., Tearle, P. V. \& Stewart, M. G. (1977). The effect of 'humanised' milks and supplemented breast feeding on the faecal flora of infants. Journal of Medical Microbiology 10, 403-413.

Bullen, C. L., Tearle, P. V. \& Willis, A. T. (1976). Bifidobacteria in the intestine of infants: an in vivo study. Journal of Medical Microbiology 9, 325-333.

Chen, W.-J., Anderson, J. W. \& Jennings, D. (1984). Propionate may mediate the hypocholesterolaemic effects of certain soluble plant fibres in cholesterol fed rats. Praceedings of the Society of Experimental Medicine 175, 215-218.

Cummings, J. H. (1981). Short chain fatty acids in the human colon. Gut 22, 763-779.

Cummings, J. H., Pomare, E. W., Branch, W. J., Naylor, C. P. E. \& Macfarlane, G. T. (1987). Short chain fatty acids in human large intestine, portal, hepatic and venous blood. Gut 28, 1221-1227.

Drasar, B. S. \& Hill, M. J. (1974). Human Intestinal Flora. New York: Academic Press.

Edwards, C. A., Bowen, J. \& Eastwood, M. A. (1990). The effect of isolated complex carbohydrates on caecal and faecal short chain fatty acids and stool output in the rat. In Dietary Fibre: Chemical and Biological Aspects, pp. 273-276 [D. A. T. Southgate, K. Waldron, I. T. Johnson and G. R. Fenwick, editors]. Cambridge: Royal Society of Chemistry.

Edwards, C. A., Bruce, M. \& Ferguson, A. (1992a). The effect of supplementing elemental diet with Dextran on colonic short chain fatty acids and cellular proliferation in the rat. Proceedings of the Nutrition Society $51,5 \mathrm{~A}$.

Edwards, C. A. \& Eastwood, M. A. (1992). Comparison of the effects of ispaghula and wheat bran on rat caecal and colonic fermentation. Gut 33, 1229-1233.

Edwards, C. A., Wilson, R. G., Hanlon, L. \& Eastwood, M. A. (1992b). Effect of the dietary fibre content of lifelong diet on colonic cellular proliferation in the rat. Gut 33, 1076-1079.

Englyst, H. N., Ay, S. \& MacFarlane, G. T. (1987). Polysaccharide breakdown by mixed populations of human faecal bacteria. Microbiology Ecology 95, 163-171.

Faelli, A. \& Esposito, G. (1970). Effect of inosine and its metabolites on intestinal iron absorption in the rat. Biochemical Pharmacology 19, 2551-2554.

Fay, J. P. \& Faries, R. N. (1975). The inhibitory action of fatty acids on the growth of Escherichia coli. Journal of General Microbiology 91, 223-240.

Floch, M. H., Binder, H. J., Filburn, B. \& Gershengoren, W. (1972). The effect of bile acids on intestinal microflora. American Journal of Clinical Nutrition 25, 1418-1426.

Florent, C., Flourie, B., Leblond, A., Raurureau, M., Bernier, J. J. \& Rambaud, J. L. (1.985). Influence of chronic lactulose ingestion on the colonic metabolism of lactulose in man (in vivo study). Journal of Clinical Investigation 75, 608-613. 
Gil, A., Corral, E., Martinez, A. \& Molina, J. A. (1986). Effects of the addition of nucleotides to an adapted milk formula on the microbial pattern of faeces in at-term newborn infants. Journal of Clinical Nutrition and Gastroenterology 1, 127-132.

Goodlad, J. S. \& Mathers, J. C. (1990). Large bowel fermentation in rats given diets containing raw peas (Pisum sativum). British Journal of Nutrition 64, 569-578.

Gorbach, S. L., Banwell, J. G., Jacobs, B., Chatterjee, B. D., Mitra, R., Sen, N. I. N. \& Guha Mazumder, D. N. (1970). Tropical sprue and malnutrition in west Bengal. I. Intestinal microflora and absorption. American Journal of Clinical Nutrition 23, 1545-1558.

Gracey, M. (1979). The contaminated small bowel syndrome: pathogenesis, diagnosis and treatment. American Journal of Clinical Nutrition 32, 234-243.

Heine, W., Wutzke, K. D., Richter, I., Walther, F. \& Plath, C. (1987). Evidence for colonic absorption of protein nitrogen in infants. Acta Paediatrica Scandinavia 76, 741-744.

Hill, M. J. (1981). Diet and the human intestinal bacterial flora. Cancer Research 41, 3778-3780.

Howie, P. W., Forsyth, J. S., Ogston, S. A., Clark, A. \& Florey, C. V. (1990). Protective effect of breast feeding against infection. British Medical Journal 300, 11-16.

Illman, R. J., Topping, D. L., McIntosh, G. H., Trimble, R. P., Storer, G. B., Taylor, M. N. \& Cheng, B.-Q. (1988). Hypocholesterolaemic effects of dietary propionate: Studies in whole animals and perfused rat liver. Annals of Nutrition and Metabolism 32, 97-107.

Jacobs, L. R. (1990). Experimental colon carcinogenesis. In Dietary Fibre Chemistry, Physiology and Health Effects, pp. 389-401 [D. Kritchevsky, C. Bonfield and J. W. Anderson, editors]. New York: Plenum Press.

Kien, C. L., Lietchy, E. A., Myerberg, D. Z. \& Mullet, M. D. (1987). Dietary carbohydrate assimilation in the premature infant: evidence for a nutritionally significant bacterial ecosystem in the colon. American Journal of Clinical Nutrition 46, 456-460.

Kirwan, W. O., Smith, A. N., Mitchell, W. D., Falconer, J. D. \& Eastwood, M. A. (1975). Bile acids and colonic motility in the rabbit and human. Gut 16, 894-902.

Kurpad, A. V. \& Shetty, P. S. (1986). Effects of antimicrobial therapy on faecal bulking. Gut 27, 55-58.

Lupton, J. R., Coder, D. M. \& Jacobs, L. R. (1988). Long term effects of fermentable fibres on rat colonic pH and epithelial cell cycle. Journal of Nutrition 118, 840-845.

McBurney, M. I., Horvath, P. J., Jeraci, J. L. \& Van Soest, P. J. (1985). Effect of in vitro fermentation using faecal inoculum on the water holding capacity of dietary fibre. British Journal of Nutrition 53, 17-24.

McBurney, M. I. \& Thompson, L. U. (1987). Effect of human faecal inoculum on in vitro fermentation variables. British Journal of Nutrition 58, 233-243.

MacLean, W. C. \& Fink, B. B. (1980). Lactose malabsorption by premature infants: magnitude and clinical significance. Journal of Pediatrics 97, 383-388.

McMillan, J. A., Oski, F. A., Lourie, G., Tomarelli, R. M. \& Landau, S. A. (1977). Iron absorption from milk, simulated mother's milk and proprietary formulas. Pediatrics 60, 896-900.

Mallett, A. K., Bearne, C. A., Young, P. J. \& Rowland, I. R. (1988). Influence of starches of low digestibility on the rat caecal microflora. British Journal of Nutrition 60, 597-604.

Mallett, A. K. \& Rowland, I. R. (1990). Bacterial enzymes and their role in the formation of mutagens and carcinogens in the intestine. Digestive Diseases and Sciences 8, 71-79.

Mekhjian, H. S., Phillips, S. F. \& Hoffman, A. F. (1971). Colonic secretion of water and electrolytes induced by bile acids: perfusion studies in man. Gastroenterology 59, 120-129.

Mevissen-Verhage, E. A. E., Marcelis, J. H., Harmsen-van Amerongen, W. C. M., de Vos, N. M. \& Verhoef, J. (1985). Effect of iron on neonatal gut flora during the first three months of life. European Journal of Clinical Microbiology 4, 273-278.

Mobassaleh, M., Montgomery, R. K., Biller, J. A. \& Grand, R. J. (1985). Development of carbohydrate absorption in the fetus and neonate. Pediatrics 75, Suppl., 160-166.

Mortensen, F. V., Nielsen, H., Mulvaney, M. J. \& Hessov, I. (1990). Short chain fatty acids dilate isolated human colonic resistance arteries. Gut 31, 1391-1394.

Owen, R., Thompsen, M., Hill, M. J., Wilpart, M., Mangurt, P. \& Roberfroid, M. (1987). The importance of the ratio of lithocholic to deoxycholic acid in large bowel carcinogenesis. Nutrition and Cancer 9, 67-71.

Rao, S. S. C., Edwards, C. A., Austin, C., Read, N. W. \& Holdsworth, C. D. (1988). Impaired colonic fermentation of carbohydrate after ampicillin. Gastroenterology 94, 928-932.

Read, N. W. \& Eastwood, M. A. (1992). Gastrointestinal physiology and function. In Dietary Fibre: a Component of Food, pp. 103-118 [T. F. Schweizer and C. A. Edwards, editors]. London: Springer Verlag.

Roediger, W. E. (1982). Utilization of nutrients by isolated epithelial cells of rat colon. Gastroenterology 83, $424-429$. 
Rowland, I. R. \& Mallett, A. K. (1990). The influence of dietary fibre on microbial enzyme activity in the gut. Irr-Dietary Fibre Chemistry, Physiology and Health Benefits, pp. 195-206 [D. Kritchevsky, C. Bonfield and J. W. Anderson, editors]. New York: Plenum Press.

Ruppin, H., Bar-meir, S., Soergel, K. H., Wood, C. M. \& Schmitt, M. G. (1980). Absorption of short chain fatty acids by the colon. Gastroenterology 78, 1500-1507.

Sakata, T. (1987). Stimulatory effect of short chain fatty acids on epithelial cell proliferation in the rat intestine: a possible explanation for the trophic effects of fermentable fibre, gut microbes and luminal trophic factors. British Journal of Nutrition 58, 95-103.

Sakata, T. (1989). Stimulatory effect of short chain fatty acids on epithelial cell proliferation of isolated and denervated jejunal segment of the rat. Scandinavian Journal of Gastroenterology 24, 886-890.

Salyers, A. A. \& Leedle, J. A. Z. (1983). Carbohydrate metabolism in the human colon. In Microflora in Health and Disease, pp. 129-146 [D. Hentges, editor]. New York: Academic Press.

Simhon, A., Douglas, J. R., Drasar, B. S. \& Soothill, J. F. (1982). Effect of feeding on infants faecal flora. Archives of Disease in Childhood 57, 54-58.

Spiller, R. C., Brown, M. L. \& Phillips, S. F. (1986). Decreased fluid tolerance, accelerated transit and abnormal motility of the human colon induced by oleic acid. Gastroenterology 91, 100-107.

Squires, P. E., Rumsey, R. D. E., Edwards, C. A. \& Read, N. W. (1992). The effect of short chain fatty acids on the contractile activity and fluid movement of the rat colon in vitro. American Journal of Physiology 262, G813-G817.

Stephen, A. M. \& Cummings, J. H. (1980). Mechanism of action of dietary fibre in the human colon. Nature 284, 283-284.

Swales, J. D., Tange, J. D. \& Wrong, O. M. (1970). The influence of pH, bicarbonate and hypertonicity on the absorption of ammonia from the rat intestine. Clinical Science 39, 769-779.

Topping, D. L., Mock, S., Trimble, R. P., Storer, G. B. \& Illman, R. J. (1988). Effects of varying the content and proportions of gum arabic and cellulose on caecal volatile fatty acid concentrations in the rat. Nutrition Research 8, 1013-1020.

Vince, A., Killingley, M. \& Wrong, O. M. (1978). Effect of lactulose on ammonia production in faecal incubation system. Gastroenterology 74, 544-549.

Walter, D. J., Eastwood, M. A. \& Brydon, W. G. (1986). An experimental design to study colonic fibre fermentation in the rat: the duration of feeding. British Journal of Nutrition 55, 465-479.

Weaver, G. A., Krause, J. A., Miller, T. L. \& Wolin, M. J. (1992). Corn starch fermentation by the colonic microbial community yields more butyrate than does cabbage fiber fermentation; corn starch fermentation rates correlate negatively with methanogenesis. American Journal of Clinical Nutrition 55, 70-77.

Wisker, E. \& Feldheim, W. (1990). Metabolism energy of diets low or high in dietary fibre from fruits and vegetables when consumed by humans. Journal of Nutrition 120, 1331-1337.

Wisker, E. \& Feldheim, W. (1992). Faecal bulking and energy value of dietary fibre. In Dietary Fibre: a Component of Food, pp. 233-246 [T. F. Schweizer and C. A. Edwards, editors]. London: Springer Verlag.

Yajima, T. (1985). Contractile effect of short chain fatty acids on the isolated colon of the rat. Journal of Physiology 368, 667-678. 